\title{
International Fisheries Management and Recreational Benefits: The Case of Baltic Salmon
}

\author{
Soile Oinonen, Finnish Environment Institute (SYKE); Lone Grønbæk, University of Southern \\ Denmark; Marita Laukkanen, VATT Institute for Economic Research; Polina Levontin, Imperial \\ College London; Marko Lindroos, Emmi Nieminen, and Katja Parkkila, University of Helsinki; \\ Pedro Pintassilgo, University of Algarve; Henni Pulkkinen, and Atso Romakkaniemi, \\ Natural Resource Institute Finland
}

\begin{abstract}
A B S T R A C T
This article studies how accounting for the benefits of recreational fisheries affects the formation and stability of an international fisheries agreement (IFA) on the management of Baltic salmon stocks. The interaction between four countries is modelled through a partition function game, under two scenarios. In the first scenario, countries take their participation decision for the IFA based only on the net present value of profits from commercial fisheries. In the second scenario, the net present value of the recreational benefits from angling is also considered. The results show that accounting for recreational benefits leads to the formation of the grand coalition, whereas only partial cooperation occurs when payoffs are confined to profits from commercial fisheries.
\end{abstract}

Key words: Baltic salmon, bioeconomic modelling, coalition games, international fisheries agreements, non-market values, shared fish stocks.

JEL Codes: C7O, F53, Q22.

\section{INTRODUCTION}

The non-cooperative management of an internationally shared fish stock implies a strategic interaction between the harvesting countries, which often results in stock overexploitation and rent dissipation (Munro 2007). In order to overcome these problems, international fisheries agreements (IFAs) on the exploitation of the resources are required. The legal framework set

Soile Oinonen is a senior research scientist, Finnish Environment Institute (SYKE), PO Box 140, FIN-00251 Helsinki, Finland (email: soile.m.oinonen@ymparisto.fi). Lone Grønbæk is an associate professor, Department of Business and Economics, University of Southern Denmark, Campusvej 55, 5230 Odense M, Denmark (email: lg@sam.sdu.dk). Marita Laukkanen is a principal research fellow, VATT Institute for Economic Research, PO Box 1279, FI-00101 Helsinki, Finland (email: marita.laukkanen @vatt.fi). Polina Levontin is a research associate, Centre for Environmental Policy, Imperial College London, Silwood Park Campus, Ascot SL5 7PY, UK (email: levontin@hotmail.com). Marko Lindroos is a university lecturer, Department of Economics and Management, PO Box 27, 00014 University of Helsinki, Finland (email: marko.lindroos@helsinki.fi). Emmi Nieminen is a doctoral student, Department of Economics and Management, PO Box 27, 00014 University of Helsinki, Finland (email: emmi.e .nieminen@helsinki.fi). Katja Parkkila is a doctoral student, Department of Economics and Management, PO Box 27, 00014 University of Helsinki, Finland (email: katja.parkkila@helsinki.fi). Pedro Pintassilgo is an assistant aggregate professor, Faculty of Economics and Research Centre for Spatial and Organizational Dynamics, University of Algarve, Campus de Gambelas, 8005-139 Faro, Portugal (email: ppintas@ualg.pt). Henni Pulkkinen is a researcher, Natural Resources Institute Finland, PO Box 413, 90014 University of Oulu, Finland (email: henni.pulkkinen@luke.fi). Atso Romakkaniemi is a researcher, Natural Resources Institute Finland, PO Box 413, 90014 University of Oulu, Finland (email: atso.romakkaniemi@luke.fi).

This work was conducted as part of the Economics of Aquatic Food Webs project, funded by the Academy of Finland's Research Programme on Sustainable Governance of Aquatic Resources. P. Pintassilgo acknowledges financial support from the Portuguese Foundation for Science and Technology, grant no. BSAB/105744/2014.

Received March 23, 2015; Accepted April 25, 2016; Published online July 27, 2016. http://dx.doi.org/10.1086/687987

Marine Resource Economics, volume 31, number 4. () 2016 MRE Foundation, Inc. All rights reserved. 0738-1360/2016/3104-0004\$10.00 
by the United Nations (UN) Convention on the Law of the Sea (United Nations 1982) and the UN Fish Stocks Agreement (United Nations 1995) stresses the relevance of these agreements in the form of regional fisheries management organizations (RFMOs).

The formation and stability of IFAs can be addressed through the use of coalition games; that is, models in which players can join together. The foundation of coalition games can be traced back to the seminal work by von Neumann and Morgenstern (1944). In the early 1960s, Thrall and Lucas (1963) introduced a specific type of coalition game called a partition function game. This type of game models the formation of an agreement endogenously and can be used to study the stability of different agreements. Partition function games were revived in the 1980s (e.g., D'Aspremont et al. 1983; Hart and Kurz 1983), and the first applications to environmental economics occurred in the 1990s (e.g., Carraro and Siniscalco 1993; Barrett 1994). Pintassilgo (2003) introduced partition function games into the fisheries economics literature.

Over the past decade, the literature on the application of partition function games to IFAs has evolved significantly (e.g., Pintassilgo and Lindroos 2008; Pintassilgo et al. 2010; Long and Flaaten 2011) and is surveyed in Lindroos, Kronbak, and Kaitala (2007) and Pintassilgo, Kronbak, and Lindroos (2015). These games are usually characterized by positive externalities (PEs) from coalition formation. That is, when a country joins an IFA it generates a positive impact on non-members' payoffs, as they can freely benefit from the cooperative efforts undertaken by the IFA's members. In this context, it is generally difficult to stabilize IFAs with a large number of countries (Pintassilgo et al. 2010). Moreover, the greater the benefits from cooperation the harder it is to achieve it, which is known as the 'paradox of cooperation' (Barrett 1994). The present article fills a gap in this literature by exploring the role of non-market benefits, such as recreational benefits for anglers, in the formation and stability of IFAs.

Fisheries can produce both market and non-market values, and the latter may form a significant part of the total economic value. Ferrara and Missios (1998), using a two-country, twoperiod model, show that non-market values affect optimal harvesting strategies. Mazzanti (2001) stresses the importance of accounting for the total economic value of whales in the international management of the species. Gong and Heal (2014) conducted an experimental fishing game and concluded that people put a positive value on endangered species but, in general, respond more to the use value than the existence value.

Even though the literature on the valuation of benefits from recreational fishing has developed (Johnston et al. 2006; Finnish Game and Fisheries Research Institute 2009; Carson 2012), there are surprisingly few applications in which non-market valuation estimates have been incorporated into the bioeconomic analysis of environmental resources, such as fish. Kulmala, Laukkanen, and Michielsens (2008) incorporated original contingent valuation results into their bioeconomic fisheries model, and Cook and McGaw (1996) applied auction prices of fishing rights in estimating the recreational benefit function for their bioeconomic framework. Recently, Hyytiäinen et al. (2015) applied results of a contingent valuation study by Ahtiainen et al. (2014) to a bioeconomic model in order to develop optimal nutrient abatement policies for the Baltic Sea catchment area. Kragt (2013) applied the results of a choice experiment in analyzing the costs and benefits of water management. The reliability of valuation results is often questioned (e.g., Hyytiäinen et al. 2015) However, in the case of salmon anglers, the valued good can be regarded as an experienced good, which makes valuation results more reliable compared to the other types of environmental goods.

This work contributes to the literature by studying the impact of accounting for recreational benefits on international fisheries management using Baltic salmon as a case study. For this pur- 
pose, the salmon fisheries in the Baltic Sea are modelled through a four-player game in partition function form. Two players (Denmark and Poland) have commercial fleets only, whereas the others (Finland and Sweden) have both commercial fleets and substantial recreational fisheries. A disaggregated bioeconomic model developed by Kulmala et al. (2013) is updated and extended to include the net benefits from recreational fisheries. Two scenarios are considered. In scenario 1, countries decide on their membership in the IFA based on the net present value of the profits from their commercial fisheries over a simulation period. In scenario 2, countries' payoffs are given by using the sum of the net present value of the profits from commercial fisheries and recreational benefits from angling.

This article is organized as follows. First, the salmon fishery in the Baltic Sea is described. Second, the bioeconomic model is presented, including the population dynamics and economic models for commercial and recreational fisheries. Third, the coalition formation game is detailed. Fourth, the main results are presented in the scenario where payoffs derive only from commercial fisheries and also in the scenario where payoffs derive from both commercial and recreational fisheries. Fifth, the implications for the salmon stocks are discussed. Finally, the main conclusions are highlighted.

\section{SALMON FISHERIES IN THE BALTIC SEA}

Baltic salmon is exploited throughout its migration routes at sea and in freshwater by fishers using various gear types. Over the last decades, the most common fishing gears have been driftnets and longlines (LL) on the offshore feeding grounds, as well as trap nets (TN) - intercepting maturing salmon on their coastal migration towards spawning rivers - and angling in the spawning rivers. Angling is the dominant recreational utilization of salmon stocks. Since the 1980s both coastal and river fisheries have increased the scale of their total catch, compared to offshore fishing (Karlsson and Karlström 1994; Romakkaniemi et al. 2003). In particular, angling and other recreational catches have increased significantly. Currently these catches account for one third of the total salmon catch in the Baltic Sea region (ICES 2014).

International management of Baltic salmon fisheries developed after a series of negotiations and conventions in the 1950s and 1960s. Eventually the 'Convention on Fishing and Conservation of the Living Resources in the Baltic Sea and the Belts' was agreed upon between the Baltic States, which also led to the establishment of the International Baltic Sea Fishery Commission (IBSFC) in 1976. The IBSFC put into practice the aims of the convention, including international fisheries management. Several Baltic countries joined the European Union in the 1990s and 2000s, which led to a wider adoption of the EU's Common Fisheries Policy (CFP) in the area. The IBSFC managed the Baltic fish resources until 2005, and the organization ceased to exist at the beginning of 2007. Thereafter, the fish resources have been managed by the European Union and by bilateral negotiations between the EU and Russia.

The European Commission has recently proposed a new long-term management plan for Baltic salmon (European Commission 2011). The most important goal is to ensure a continued recovery of natural reproduction and to eventually attain at least $75 \%$ of the estimated potential smolt production capacity of wild salmon in each river, at the latest after ten years from the entry into force of the plan. The total allowable catch (TAC) based management considers only commercial fisheries. However, the management plan acknowledges both the commercial and recreational user groups, lists objectives for the growing recreational fishing sector, and proposes several obligations to the member states for managing recreational fishing in the spawning rivers according to the set of objectives and management practices. The plan also reminds 
the member states about their obligations deriving from Article 66 of United Nations Convention on the Law of the Sea (United Nations 1982), which requires inter alia that the state of origin of anadromous stocks and other states concerned should cooperate with regard to conservation and management of these stocks.

\section{BIOECONOMIC MODEL}

The bioeconomic model adopted herein is based on Kulmala et al. (2013) and the stockassessment models currently used in Baltic salmon stock assessment (Michielsens and Murdoch 2004; Michielsens et al. 2006; Michielsens et al. 2008). A novelty of the present bioeconomic model is that it accounts for recreational net benefits from the river harvests. Moreover, the model is forward looking, considers only wild salmon stocks, and the fleet structure of each player is updated to follow the EU ban on driftnets in the Baltic Sea (Council Regulation (EC) No 2187/2005).

Figure 1 and table 1 present an overview of the part of the model that addresses the annual cycle of feeding and spawning migration and sequential harvest of 15 wild salmon stocks by different countries and with different gear types. The main countries harvesting salmon in the Baltic Sea are considered to be: Poland (PL), Denmark (DK), Finland (FI) and Sweden (SE). Together, these countries catch nearly $90 \%$ of the annual commercial salmon catch (Kulmala et al. 2013). Poland, Denmark, and Finland use LL in the Baltic Main Basin. In the model, this winter fishery is assumed to occur in December. In summer, the maturing salmon

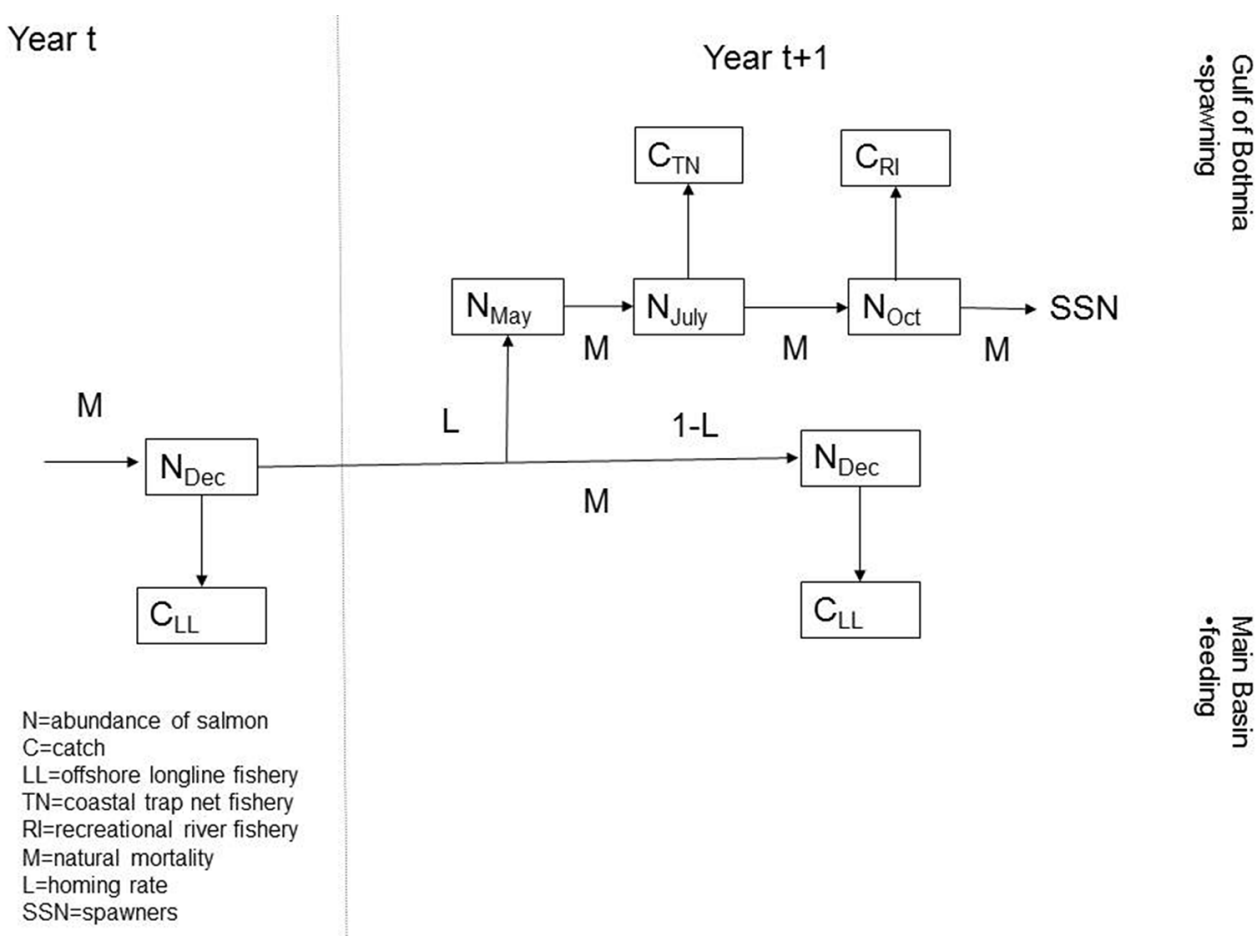

Figure 1. Schematic Presentation of the Annual Occurrence and Migration of Baltic Salmon and the Harvest by Different Fisheries 
Table 1. Fleet Structure of Each Country, Target Salmon Stocks of Each Fleet, and the Division of Salmon Stocks into ICES Stock Assessment Units

\begin{tabular}{|c|c|c|c|c|c|c|c|}
\hline \multirow[b]{2}{*}{ Salmon Stock } & \multirow{2}{*}{$\frac{\text { Poland }}{\text { Longline }}$} & \multirow{2}{*}{$\frac{\text { Denmark }}{\text { Longline }}$} & \multicolumn{3}{|c|}{ Finland } & \multicolumn{2}{|c|}{ Sweden } \\
\hline & & & Longline & Trap Net & River & Trap Net & River \\
\hline \multicolumn{8}{|l|}{ Assessment unit 1} \\
\hline Tornionjoki* & $\mathrm{x}$ & $\mathrm{x}$ & $\mathrm{x}$ & $\mathrm{x}$ & $\mathrm{x}$ & & $\mathrm{x}$ \\
\hline Simojoki* & $\mathrm{x}$ & $\mathrm{x}$ & $\mathrm{x}$ & $\mathrm{x}$ & $\mathrm{x}$ & & \\
\hline Kalixälven* & $\mathrm{x}$ & $\mathrm{x}$ & $\mathrm{x}$ & $\mathrm{x}$ & & & $\mathrm{x}$ \\
\hline Råneälven & $\mathrm{x}$ & $\mathrm{x}$ & $\mathrm{x}$ & $\mathrm{x}$ & & & \\
\hline \multicolumn{8}{|l|}{ Assessment unit 2} \\
\hline Piteälven & $\mathrm{x}$ & $\mathrm{x}$ & $\mathrm{x}$ & $\mathrm{x}$ & & $\mathrm{x}$ & \\
\hline Åbyälven & $\mathrm{x}$ & $\mathrm{x}$ & $\mathrm{x}$ & $\mathrm{x}$ & & $\mathrm{x}$ & \\
\hline Byskeälven* & $\mathrm{x}$ & $\mathrm{x}$ & $\mathrm{x}$ & $\mathrm{x}$ & & $\mathrm{x}$ & $\mathrm{x}$ \\
\hline Rickleån & $\mathrm{x}$ & $\mathrm{x}$ & $\mathrm{x}$ & $\mathrm{x}$ & & $\mathrm{x}$ & \\
\hline Sävarån & $\mathrm{x}$ & $\mathrm{x}$ & $\mathrm{x}$ & $\mathrm{x}$ & & $\mathrm{x}$ & \\
\hline Ume/Vindelälven* & $\mathrm{x}$ & $\mathrm{x}$ & $\mathrm{x}$ & $\mathrm{x}$ & & $\mathrm{x}$ & $\mathrm{x}$ \\
\hline Öreälven & $\mathrm{x}$ & $\mathrm{x}$ & $\mathrm{x}$ & $\mathrm{x}$ & & $\mathrm{x}$ & \\
\hline Lögdeälven & $\mathrm{x}$ & $\mathrm{x}$ & $\mathrm{x}$ & $\mathrm{x}$ & & $\mathrm{x}$ & \\
\hline \multicolumn{8}{|l|}{ Assessment unit 3} \\
\hline Ljungan & $\mathrm{x}$ & $\mathrm{x}$ & $\mathrm{x}$ & $\mathrm{x}$ & & $\mathrm{x}$ & \\
\hline \multicolumn{8}{|l|}{ Assessment unit 4} \\
\hline Mörrumsån* & $\mathrm{x}$ & $\mathrm{x}$ & $\mathrm{x}$ & & & & $\mathrm{x}$ \\
\hline Emån & $\mathrm{x}$ & $\mathrm{x}$ & $\mathrm{x}$ & & & & \\
\hline
\end{tabular}

* Salmon stocks with recreational fisheries.

migrate to spawn in their natal rivers, and during the migration they are harvested by Finnish and Swedish TN. Before spawning, the escaped salmon originating from a total of six rivers are harvested by recreational fishers (RI) in Sweden and Finland (table 1). The situation described in the fisheries corresponds to that prevailing in 2012, from March to the end of the year (ICES 2013).

\section{POPULATION DYNAMICS MODEL}

The population dynamics model is discrete in time, age-structured, and parameterized using the International Council for the Exploration of the Sea (ICES) stock assessment results (ICES 2012). This assessment is annually updated and peer-reviewed following the scientific quality assurance procedures of ICES fish stock assessments. The population dynamics of 15 wild salmon stocks is as follows:

$$
N_{a+1, y+1, a u, s e, s t}=N_{a, y, a u, s e, s t} e^{-q_{a, y, f} E_{y, a u, f}} e^{-m_{a, y}},
$$

where $N_{a, y, a u, s e, s t}$ is the abundance of salmon by age ( $a$ ), year $(y)$, assessment unit ( $\left.a u\right)$, season ( $e$ ), and stock $(s t) ; q_{a, y, f}$ is the catchability coefficient by age, year, and fishing method $(f) ; E_{y, a u, f}$ is the fishing effort; and $m_{a, y}$ the instantaneous natural mortality rate. The season dimension separates mature and immature salmon. The natural mortality of mature salmon is higher than the average rate due to seal predation. The abundance of mature salmon migrating back to natal rivers is given by:

$$
N_{a, y, a u, s e=2, s t}=L_{a} N_{a, y, a u, s e=1, s t} e^{-q_{a, y, f} E_{y, a u, f}} e^{-m_{a, y}},
$$


where $\left(L_{a}\right)$ is the homing rate. The number of immature salmon is given by:

$$
N_{a, y, a u, s e=1, s t}=\left(1-L_{a}\right) N_{a, y, a u, s e=1, s t} e^{-q_{a, y, f} E_{y, a u, f}} e^{-m_{a, y}} .
$$

Spawners are mature salmon that have escaped from the fishery. By assumption, all salmon die after spawning. The number of eggs produced is given by:

$$
N_{e g g, y, a u, s e=2, s t}=S S N_{a, y, a u, s e=2, s t} r s_{a} f e_{y, a u, s e=2},
$$

where $S S N$ is the number of spawners, $r s$ is the sex ratio, and $f e$ is the fecundity.

It takes salmon approximately four years to develop from eggs to smolts (juveniles). At the alevin stage, salmon face a reproduction disorder, known as M74-syndrome, which in some years increases natural mortality in the juvenile phase (Karlsson and Karlström 1994). The egg-smolt relationship follows a Beverton-Holt stock-recruitment function as follows:

$$
N_{\text {smolt }, y+4, a u, s e=2, s t}=\frac{N_{e g g, y, a u, s e=2, s t}\left(1-m_{y}^{74}\right)}{\alpha+\beta N_{e g g, y, a u, s e=2, s t}\left(1-m_{y}^{74}\right)},
$$

where $\alpha$ and $\beta$ are recruitment parameters and the mortality rate caused by the M74-syndrome is denoted by $m_{y}^{74}$.

\section{COMMERCIAL FISHERY MODEL}

The population dynamics model depends on the aggregate fishing effort and catch by fish stock assessment unit (i.e., a group of river stocks with similar sea migration is assumed to be exploited similarly by sea fisheries (table 1$)$ ). The catches per country and gear type are calculated by defining a coefficient $j=g X$, where $g$ is a parameter and $X$ is a country's $(i)$ share of the aggregate fishing effort in a given assessment unit: $X=\frac{E_{f, i}}{E_{a u, f}}$, where $E_{a u, f}=\sum_{i=1}^{n} E_{a u, f, i}$ (Kulmala 2009; Kulmala et al. 2013).Throughout the model we denote the number of salmon available to gear type $f$, with age $a$ in assessment unit $a u$, by $N_{a, a u, f}$. Similarly, $p_{f, i}$ and $c_{f, i}$ refers to the salmon price and fishing costs, respectively, of country $i$ when using gear type $f$. The average catch weight of salmon by sea-age ${ }^{1}$ and gear type is represented by $W_{a, f}$. The total effort of country $i$ using gear type $f$ is the sum of fishing efforts over all assessment units: $E_{f, i}=\Sigma_{a u} E_{a u, f, i}$.

As shown in table 1, the Finnish commercial Baltic Salmon fisheries use LL and TN. The Swedish commercial fisheries are limited to TN, whereas Poland and Denmark use LL. In July, the Finnish and Swedish fleets use TN to harvest salmon that have escaped from the offshore fisheries. Due to the migration pattern, salmon from assessment units $1-3$ and 2-3 are available to the Finnish and Swedish fleets, respectively. The annual profits for the Finnish and Swedish fleets employing TN are given by equations (6) and (7), respectively:

$$
\begin{aligned}
& \operatorname{PROF}_{y, t n, F I}=p_{t n, F I}\left\{\sum_{a=1}^{5}\left[\sum_{a u=1}^{3}\left(j_{a u, t n, F I} N_{a, a u, t n}\left(1-e^{-q_{a, a u, t n} E_{a u, t n}}\right)\right)\right] W_{a, t n}\right\}-c_{t n, F I} E_{t n, F I} \\
& \operatorname{PROF}_{y, t n, S E}=p_{t n, S E}\left\{\sum_{a=1}^{5}\left[\sum_{a u=2}^{3}\left(j_{a u, t n, S E} N_{a, a u, t n}\left(1-e^{-q_{a, a u, t n} E_{a u, t n}}\right)\right)\right] W_{a, t n}\right\}-c_{t n, S E} E_{t n, S E} .
\end{aligned}
$$

1. The salmon age $a=0$ refers to smolts, which are not harvested; age $=1$ refers to salmon that have spent 1 winter at sea (1 SW); age $=2-5$ refers to multi-sea-winter (MSW) salmon. 
In December, the immature salmon (eq. 3) are harvested in the offshore area (the Baltic Main Basin) using LL. This fishing method is used by all countries except Sweden (table 1). The annual profits for country $i$, employing LL is given by:

$$
\operatorname{PROF}_{y, l l, i}=p_{l l, i}\left[\sum_{a=1}^{5}\left(\sum_{a u=1}^{4}\left(j_{a u, l l, i} N_{a, a u, l l}\left(1-e^{-q_{a, l} E_{a u, l l}}\right)\right)\right) W_{a, l l}\right]-c_{l l, i} E_{l l, i} .
$$

The aggregate profit of a country from commercial fisheries is given by:

$$
\mathrm{PROF}_{y, i}=\sum_{f} P R O F_{y, f, i}
$$

\section{RECREATIONAL FISHERY MODEL}

Finland and Sweden also have recreational fisheries that target salmon in their home rivers, where they reproduce. The mature salmon escaping from the coastal trap nets are harvested by anglers during the months of August and September when they reach their home rivers. Virtually all salmon die after spawning. The annual river harvest is as follows:

$$
R I C_{r}=\sum_{a=1}^{5}\left[N_{a, r}\left(1-e^{-h_{a, r}}\right)\right] W_{a}
$$

where $N_{a, r}$ is the number of salmon available for the fishery in river $r$, and $h_{a, r}$ is the age and river-specific harvest rate, which is assumed to be constant over time and is parameterized using the ICES (2012) estimate for 2011. Equation (10) implies that harvest by river fisheries is determined by the number of salmon that escape both the offshore and the coastal fisheries. Thus, the effective recreational catch is determined by the fishing effort undertaken in the commercial fisheries. Several authors have used river catch as an index of spawning run size, indicating that the harvest rate in river fishing is fairly constant (e.g., Chadwick 1985; Karlsson and Karlström 1994; Romakkaniemi et al. 2003). The Baltic salmon stock assessment model is fitted to the historic time series of river catches; these results indicate fairly similar harvest rates in river fishing over the last two decades (e.g., ICES 2012, 220).

In modeling the net benefits of the recreational harvest, we follow Cook and McGaw (1996), Kulmala et al. (2008), and Olaussen and Skonhoft (2008) and assume a linear marginal willingness to pay (WTP) for recreational harvest. We assume away heterogeneity in the angler population, as our focus is on the qualitative effect of accounting for the benefits from recreational harvest on the potential for international cooperation (partial versus full cooperation). In practice, there will be differences in angler skill that affect individual catch rates; careful micro modelling of angler heterogeneity would produce more accurate management guidelines but would be unlikely to change the qualitative results on the extent of international cooperation. In order to estimate the individual net benefit function for an average fisherman, we compute the integral of the estimated marginal WTP between fixed levels of current and improved catch. These individual net benefits are then aggregated across the angler population to obtain parameters of the aggregated net benefit function:

$$
N B R_{r}=k R I C_{r}-\nu R I C_{r}^{2},
$$

where $k$ and $v$ are functional parameters. 
Thus, for a given country, the aggregate recreational benefits are given by:

$$
N B R_{i}=\sum_{r} N B R_{r, i}, \text { where } i \in\{F I, S E\} .
$$

Marginal WTP estimates based on previous contingent valuation studies are available for the following rivers: Simojoki (Parkkila 2005), Tornionjoki (both in the Finnish and the Swedish side) (Finnish Game and Fisheries Research Institute 2009), Byskeälven (Appelblad 2001), and Ume/Vindelälven (Håkansson 2008). We assume that the number of anglers and their preferences in the Kalixälven and Mörrumsån Rivers are similar to those in Tornionjoki (Swedish side) and Byskeälven. Table 2 presents the estimated parameters of the net benefit function for each river.

There is a considerable literature on the economic valuation of the benefits from recreational fishing (for a review see Johnston et al. 2006). Empirical evidence shows that recreational fishing benefits are positively related to the fish catch and Johnston et al. (2006) found that this relationship is particularly strong for salmon species. The quadratic function form of the aggregated net benefit (equation (11)) implies that anglers' benefits increase at a decreasing rate with additional catch. This is supported by economic theory and empirical valuation studies on fisheries (Cantrell et al. 2004; Johnston et al. 2006). Moreover, in a number of bioeconomic frameworks on salmon fisheries, demand for recreational fishing is specified as a linear function of catch (Cook and McGaw 1996; Kulmala, Laukkanen, and Michielsens 2008; Olaussen and Skonhoft 2008).

\section{COALITION FORMATION GAME}

We model the formation of an international fishery agreement (IFA) on the Baltic salmon fisheries through a two-stage partition function game with four players: Denmark, Finland, Poland, and Sweden. This game, denoted as $\Gamma(N, \Pi)$, is fully defined by the set of players, $N=\{1,2,3,4\}$, and the partition function, $\Pi$. This function associates the corresponding payoffs with each possible coalition structure, or partition of the set of players. It is assumed that only one nontrivial coalition; that is, with more than one player, will form. Thus, a coalition structure can be represented by $C=\left\{S, 1_{(n-m)}\right\}$, where $S$ represents the coalition composed of $m$ members, $m \in\{1,2,3,4\}$, and $1_{(n-m)}$ the vector of $n-m$ singletons. In this context, the overall coalition structure is fully characterized by coalition $S$. In the first stage, each country decides whether to join the IFA (coalition) or be a non-member and act as a singleton. A single coalition and openmembership setting (D'Aspremont et al. 1983) is assumed; that is, only one coalition forms and any country is allowed to join it. These assumptions are based on the legal setting of the UN Con-

Table 2. Parameters of the River Net Benefit Functions

\begin{tabular}{lrc}
\hline & \multicolumn{2}{c}{ Parameter } \\
\cline { 2 - 3 } Salmon Stock & $\mathrm{k}$ & $\mathrm{v}$ \\
\hline Byskeälven & 11.5 & 0.0006 \\
Simojoki & 46.5 & 0.006 \\
Tornionjoki, Finland & 22.5 & 0.0004 \\
Tornionjoki, Sweden & 24.4 & 0.003 \\
Ume/Vindelälven & 3.9 & 0.002 \\
\hline
\end{tabular}


vention on the Law of the Sea (United Nations 1982) and the UN Fish Stocks Agreement (United Nations 1995), according to which an internationally shared fish stock should be managed through an RFMO. According to article 8 of the UN Fish Stocks Agreement, this organization should be open to all countries with "a real interest in the fisheries concerned."

In the first stage, the stable coalitions are determined using the concepts of internal and external stability, which is de facto a Nash equilibrium in membership strategies:

$$
\begin{aligned}
& \text { Internal stability: } \prod_{i}^{*}(S) \geq \prod_{i}^{*}(S \backslash\{i\}) \forall i \in S \\
& \text { External stability: } \prod_{j}^{*}(S) \geq \prod_{j}^{*}(S \cup\{j\}) \forall j \notin S,
\end{aligned}
$$

where $\pi_{i}^{*}(S)$ and $\Pi_{j}^{*}(S)$ denote the payoff for member country, $i$, and non-member, $j$, when coalition $S$ forms, respectively. $\pi_{i}^{*}(S \backslash\{i\})$ represents the payoff for player $i$ when it withdraws from coalition $S$ and becomes a singleton, and $\Pi_{j}^{*}(S \cup\{j\})$ for the payoff for player $j$ when it joins coalition $S$. According to the concept of internal stability (13), no signatory should have an incentive to leave coalition $S$ to become a non-signatory. External stability (14) means that no non-signatory should have an incentive to join coalition $S$. Coalitions that are both internally and externally stable are called stable.

In the second stage, given that some coalition $S$ has formed in the first stage, players choose their commercial fishing effort levels (see equations (6)-(9)). It is assumed that signatories derive their equilibrium effort levels by maximizing the sum of the net benefits of the coalition members, and singletons maximize their own payoffs. The equilibrium of the second stage is given by the Nash equilibrium fishing efforts. Inserting these equilibrium fishing efforts into the payoffs for each coalition structure yields the partition function.

Regarding the sharing of coalitional payoffs among its members, we assume the "almost ideal sharing scheme" (AISS), proposed by Eyckmans and Finus (2004). This scheme allocates to each coalition member their free-rider payoff, $\Pi_{i}(S \backslash\{i\})$, plus a share, $\lambda_{i}(S)$, of the coalitional surplus over the sum of free-rider payoffs, $\Delta(S)$ :

$$
\prod_{i}(S)=\prod_{i}(S \backslash\{i\})+\lambda_{i}(S) \operatorname{CSURP}(S),
$$

where $\left.\operatorname{CSURP}(S)=\Sigma_{i \in S} \prod_{i}(S)-\Sigma_{i \in S} \Pi_{i}(S \backslash\{i\}), \lambda_{i} \in\right] 0,1\left[\right.$ and $\Sigma_{i \in S} \lambda_{i}=1$. Thus, under the AISS, coalition $S$ is internally stable (see equation (13)) if and only if its coalitional surplus is non-negative, $\operatorname{CSURP}(S) \geq 0$, irrespective of the sharing weightings, $\lambda_{i}(S)$. This sharing scheme establishes a direct link between internal and external stability (equation (14)): if coalition $S$ is internally stable, then all coalitions $S \backslash\{i\}$ are not externally stable.) Eyckmans and Finus (2004) show that the AISS stabilizes those coalitions generating the highest possible aggregate payoff among the set of coalitions with non-negative coalitional surplus. Moreover, under this scheme the stable coalitions do not depend on the sharing weightings, $\lambda_{i}(S)$.

The game is solved backwards for the subgame perfect equilibrium. That is, we start by solving the second stage by determining the Nash equilibrium fishing efforts for all possible coalition structures. Then, using these equilibrium fishing efforts the partition function is obtained, which is the sharing of the coalition payoff among its members undertaken through the AISS. Finally, applying the concepts of internal and external stability gives the equilibrium coalition structure.

Lastly, we test the game for two standard properties of IFA games: positive externalities (PEs) and global efficiency of cooperation (GEC). Consider $S$ and $S^{\prime}=S \cup\{j\}$ as any two coalitions 
formed in the first stage where $S^{\prime}$ is obtained from the merger of coalition $S$ and player $j$. A partition function game exhibits PEs if and only if the payoff for a player $\ell$, who is neither a member of coalition $S$ nor $S^{\prime}$, is strictly higher under $S^{\prime}$ than under $S: \prod_{\ell \notin S^{\prime}}\left(S^{\prime}\right)>\prod_{\ell \notin S}(S)$. PEs mean that the merger of coalitions increases the payoffs of the non-merging players. Therefore, IFAs are rarely self-enforcing (Yi 1997). GEC holds if and only if the aggregate payoff is strictly higher under $S^{\prime}$ than $S: \Sigma_{i \in S^{\prime}} \prod_{i}\left(S^{\prime}\right)+\Sigma_{\ell \notin S^{\prime}} \prod_{\ell}\left(S^{\prime}\right)>\Sigma_{i \in S} \Pi_{i}(S)+\Sigma_{\ell \notin S} \Pi_{\ell}(S)$. GEC means that mergers of coalitions increase the aggregate payoffs.

\section{SCENARIOS}

The four-player partition function game analyses the IFA of the Baltic salmon fisheries over a 20-year simulation period: 2011-2030. Two scenarios are considered. At first, the players' payoffs consist of commercial profits, and second, the payoffs are sum of the commercial profits and recreational values. In both scenarios, the decision variables of the countries are the fishing efforts of the commercial fisheries. The economic model parameters for the commercial fleet are from Kulmala (2009) and Kulmala et al. (2013).

\section{SCENARIO 1: COMMERCIAL FISHERIES ONLY}

In scenario 1 (S1), the payoff for each country is given by the net present value of the profits from commercial fisheries. A coalition maximizes the sum of the payoffs for its members by choosing the vector of their fishing efforts $\left(E_{M}\right)$, given the vector of fishing efforts of the singletons $\left(E_{N M}\right)$ :

$$
\max _{E_{M}} \sum_{i \in S} \prod_{i}=\sum_{i \in S} \sum_{y=2011}^{2030} \frac{\operatorname{PROF}_{y, i}\left(E_{M}, E_{N M}\right)}{(1+\delta)^{y-2011}} .
$$

Each singleton chooses the constant level of fishing effort $\left(E_{j}\right)$ that maximizes its own net present value of profits from commercial fisheries, given the vector of coalition member efforts $\left(E_{M}\right)$ and the vector of fishing efforts of the other singletons $\left(E_{N M \mid\{j\}}\right)$ :

$$
\max _{E_{j}} \prod_{j \notin S}=\sum_{y=2011}^{2030} \frac{\operatorname{PROF}_{y, j}\left(E_{M}, E_{j}, E_{N M \mid\{j\}}\right)}{(1+\delta)^{y-2011}} .
$$

\section{SCENARIO 2: RECREATIONAL NET BENEFITS INCLUDED}

In scenario 2 (S2), the net present values of the benefits from recreational fisheries are included in the players' payoffs. A coalition, $S$, and each singleton, $j \notin S$, solve the following problems, respectively:

$$
\begin{aligned}
& \max _{E_{M}} \sum_{i \in S} \prod_{i}=\sum_{i \in S}\left(\sum_{y=2011}^{2030} \frac{P R O F_{y, i}\left(E_{M}, E_{N M}\right)}{(1+\delta)^{y-2011}}+\sum_{y=2011}^{2030} \frac{N B R_{y, i}\left(E_{M}, E_{N M}\right)}{(1+\delta)^{y-2011}}\right) \\
& \max _{E_{j}} \prod_{j \notin S}=\sum_{y=2011}^{2030} \frac{P R O F_{y, j}\left(E_{M}, E_{j}, E_{N M \mid\{j\}}\right)}{(1+\delta)^{y-2011}}+\sum_{y=2011}^{2030} \frac{N B R_{y, i}\left(E_{M}, E_{j}, E_{N M \mid\{j\}}\right)}{(1+\delta)^{y-2011}} .
\end{aligned}
$$

The coalition maximizes the aggregate payoff for its members, given by the sum of net present values of profits from commercial fisheries and net recreational benefits. The decision variable 
is the vector of commercial fishing efforts of its members $\left(E_{M}\right)$, given the vector of commercial fishing efforts of the singletons $\left(E_{N M}\right)$. Each singleton chooses a constant level of commercial fishing effort $\left(E_{j}\right)$ that maximizes its own sum of net present values of profits from commercial fisheries and the net recreational benefits, given the vector of coalition members' commercial efforts $\left(E_{M}\right)$ and the vector of commercial fishing efforts of the other singletons $\left(E_{N M \mid\{j\}}\right)$.

The payoff for Finland consists of the net present value of the LL and TN profits and the net benefits of the recreational fisheries from the Simojoki and Tornionjoki Rivers. Sweden's payoff includes the net present value of trap net profits and the net benefits from recreational fisheries from the Tornionojoki, Kalixälven, Byskeälven, Ume/Vindelälven, and Mörrumsån rivers. In both scenarios, the payoffs of Poland and Denmark are confined to the net present value of profits from the LL fisheries (table 1).

\section{RESULTS}

Tables 3 and 4 show the results of the partition function game of the two scenarios. The Nash equilibrium fishing effort strategies of each player are shown as a ratio to the reported fishing effort in the base year (2010). In the case of Finland, it is assumed that this ratio is the same for the LL and TN gears. The payoff for each player under all possible coalition structures is also shown. Each coalition is represented by including its members inside parentheses. For instance, coalition structure $1(\mathrm{C} 1)$ stands for the case in which all players behave non-cooperatively as singletons. Under C2, Finland and Sweden form a coalition, whereas Poland and Denmark are singletons. The grand coalition, composed of the four players, is represented by C12.

Table 3 shows that in scenario 1 full non-cooperation (C1) implies that all players increase their fishing effort compared to the base year. In particular, Finland chooses a fishing effort which is 3.2 times the fishing effort in 2010; that is, an increase of $220 \%$. On the other hand, full non-cooperation (C1) in scenario 2 implies that it is optimal for Sweden to give up commercial fisheries and earn net benefits from only the recreational fisheries (table 4). In both scenarios, the merger of players into coalitions increases the aggregate payoff; thus both games are characterized by the property of GEC. For example, in scenario 2 the aggregate payoffs increase from 64.3 million euros in non-cooperation (C1) to 139.2 million euros in a grand coalition (C12) (table 4). In general, recreational values increase the aggregate payoffs. For the grand coalition (C12), in particular, payoffs are 2.5 times higher in scenario 2 than scenario 1 . Moreover, both scenarios satisfy the standard property of IFA games; i.e., PEs which mean that the merger of coalitions increases the payoff for the non-merging players. For example, when Finland and Sweden form coalition (C2), the payoffs for the non-merging countries, Poland and Denmark, increase.

The stability analysis (equations (13) and (14)) shows that there are three stable coalition structures in scenario 1 and one stable coalition structure in scenario 2 . The three stable coalition structures in scenario 1 are $\mathrm{C} 8, \mathrm{C} 10$ and $\mathrm{C} 11$, which are partial agreements between three players: (FI, SE, DK), (PL, DK, FI), and (PL, DK, SE) (table 3). Under these three agreements, due to the differences in the countries' harvesting efficiency and the number of salmon available to their fleet, it is optimal to allocate all the fishing effort in the commercial fisheries either to Finland or Sweden and then compensate the other countries through the AISS. In particular, in $\mathrm{C} 10$ - the stable coalition with the highest aggregate payoff - all the fishing effort of the coalition (PL, DK, FI) is undertaken by Finland, with a fishing effort 3.8 times that of the base year. 
Table 3. Scenario 1: Fishing Effort Strategies, Payoffs, and Stability Analysis

\begin{tabular}{|c|c|c|c|c|c|c|c|}
\hline \multirow[b]{2}{*}{ Coalition Structure } & \multirow[b]{2}{*}{ Poland } & \multirow[b]{2}{*}{ Denmark } & \multirow[b]{2}{*}{ Finland } & \multirow[b]{2}{*}{ Sweden } & \multirow[b]{2}{*}{ Total M€ } & \multicolumn{2}{|c|}{ Stability } \\
\hline & & & & & & Internal & External \\
\hline $1 \mathrm{PL}, \mathrm{DK}, \mathrm{FI}, \mathrm{SE}$ & & & & & & yes & no \\
\hline Strategy & 1.8 & 2.6 & 3.2 & 1.2 & & & \\
\hline Payoff & 5.6 & 0.5 & 11.6 & 1.1 & 18.8 & & \\
\hline $2 \mathrm{PL}, \mathrm{DK},(\mathrm{FI}, \mathrm{SE})$ & & & & & & yes & no \\
\hline Strategy & 1.8 & 2.8 & $3.4^{*}$ & $0^{*}$ & & & \\
\hline Payoff & 5.8 & 0.6 & 12.5 & 2.0 & 21.0 & & \\
\hline 3 PL, (DK, FI), SE & & & & & & yes & no \\
\hline Strategy & 1.8 & $0^{*}$ & $3.6^{*}$ & 1.4 & & & \\
\hline Payoff & 6.6 & 1.8 & 12.9 & 1.9 & 23.1 & & \\
\hline $4(\mathrm{PL}, \mathrm{FI}), \mathrm{DK}, \mathrm{SE}$ & & & & & & yes & no \\
\hline Strategy & $0^{*}$ & 6.6 & $3.8^{\star}$ & 2.4 & & & \\
\hline Payoff & 6.9 & 4.7 & 12.9 & 6.0 & 30.5 & & \\
\hline 5 PL, (DK, SE), FI & & & & & & yes & no \\
\hline Strategy & 1.8 & $0^{*}$ & 3.4 & $1.6^{*}$ & & & \\
\hline Payoff & 6.7 & 0.8 & 14.1 & 1.4 & 23.0 & & \\
\hline $6(\mathrm{PL}, \mathrm{SE}), \mathrm{DK}, \mathrm{FI}$ & & & & & & no & yes \\
\hline Strategy & $0^{*}$ & 6.4 & 4 & $2.4^{*}$ & & & \\
\hline Payoff & 5.0 & 4.6 & 20.2 & 0.6 & 30.4 & & \\
\hline 7 (PL, DK), FI, SE & & & & & & yes & no \\
\hline Strategy & $1.8^{*}$ & $0^{*}$ & 3.6 & 1.4 & & & \\
\hline Payoff & 5.8 & 0.8 & 14.6 & 1.9 & 23.1 & & \\
\hline $8 \mathrm{PL},(\mathrm{FI}, \mathrm{SE}, \mathrm{DK})$ & & & & & & yes & yes \\
\hline Strategy & 2 & $0^{*}$ & $3.6^{*}$ & $0^{*}$ & & & \\
\hline Payoff & 7.2 & 0.7 & 14.1 & 2.0 & 24.0 & & \\
\hline 9 (PL, FI, SE), DK & & & & & & no & yes \\
\hline Strategy & $0^{*}$ & 7.2 & $3.8^{\star}$ & $0.4^{*}$ & & & \\
\hline Payoff & 4.3 & 5.7 & 18.7 & 4.4 & 33.1 & & \\
\hline 10 (PL, DK, FI), SE & & & & & & yes & yes \\
\hline Strategy & $0^{*}$ & $0^{*}$ & $3.8^{*}$ & 4.2 & & & \\
\hline Payoff & 7.4 & 5.6 & 15.5 & 19.6 & 48.1 & & \\
\hline 11 (PL, DK, SE), FI & & & & & & yes & yes \\
\hline Strategy & $0^{*}$ & $0^{*}$ & 4.6 & $3.8^{*}$ & & & \\
\hline Payoff & 7.2 & 5.1 & 30.7 & 2.5 & 45.5 & & \\
\hline 12 (PL, DK, FI, SE) & & & & & & no & yes \\
\hline Strategy & $0^{*}$ & $0^{*}$ & $0.8^{*}$ & $4.6^{*}$ & & & \\
\hline Payoff & 5.3 & 3.9 & 28.9 & 17.8 & 55.9 & & \\
\hline
\end{tabular}

Note: Coalition members are shown in parentheses. Payoff of each player and the total payoff are in million euros $(\mathrm{M} €)$. Strategy is the Nash equilibrium fishing effort strategy of each player shown as a ratio to the reported fishing effort in the base year (2010).

* Strategy of the coalition member.

Coalition structure C10 is internally stable, as the aggregate payoff for the coalition (28.5 million euros) is larger than the sum of the free rider payoffs for Poland (6.6 million euros), Denmark (4.7 million euros), and Finland (14.6 million euros), yielding a positive coalition surplus (2.6 million euros). This agreement is externally stable, as Sweden has no incentive to join it. In fact, its payoff would be reduced from 19.6 million euros to 17.8 million euros when joining coalition structure $\mathrm{C} 10$ and thus forming a grand coalition.

In scenario 2, the grand coalition (C12) becomes the only stable coalition structure. The optimal fishing strategy of this stable agreement is to give up commercial fisheries and increase 
Table 4. Scenario 2: Fishing Effort Strategies, Payoffs, and Stability Analysis

\begin{tabular}{|c|c|c|c|c|c|c|c|}
\hline \multirow[b]{2}{*}{ Coalition Structure } & \multirow[b]{2}{*}{ Poland } & \multirow[b]{2}{*}{ Denmark } & \multirow[b]{2}{*}{ Finland } & \multirow[b]{2}{*}{ Sweden } & \multirow[b]{2}{*}{ Total M€ } & \multicolumn{2}{|c|}{ Stability } \\
\hline & & & & & & Internal & External \\
\hline $1 \mathrm{PL}, \mathrm{DK}, \mathrm{FI}, \mathrm{SE}$ & & & & & & yes & no \\
\hline Strategy & 2 & 3.8 & 1.2 & 0 & & & \\
\hline Payoff & 6.9 & 1.1 & 24.8 & 31.5 & 64.3 & & \\
\hline $2 \mathrm{PL}, \mathrm{DK},(\mathrm{FI}, \mathrm{SE})$ & & & & & & yes & no \\
\hline Strategy & 2.2 & 4 & $0^{*}$ & $0^{*}$ & & & \\
\hline Payoff & 7.6 & 1.2 & 26.9 & 33.6 & 69.3 & & \\
\hline $3 \mathrm{PL},(\mathrm{DK}, \mathrm{FI}), \mathrm{SE}$ & & & & & & yes & no \\
\hline Strategy & 2.2 & $0^{*}$ & $1.6^{*}$ & 0 & & & \\
\hline Payoff & 8.8 & 2.5 & 26.2 & 32.2 & 69.7 & & \\
\hline $4(\mathrm{PL}, \mathrm{FI}), \mathrm{DK}, \mathrm{SE}$ & & & & & & yes & no \\
\hline Strategy & $0^{*}$ & 8 & $2.4^{*}$ & 0.6 & & & \\
\hline Payoff & 9.7 & 7.1 & 27.6 & 35.7 & 80.1 & & \\
\hline $5 \mathrm{PL},(\mathrm{DK}, \mathrm{SE}), \mathrm{FI}$ & & & & & & no & no \\
\hline Strategy & 2.2 & $0^{*}$ & 1.6 & $0^{*}$ & & & \\
\hline Payoff & 8.8 & 0.9 & 28.6 & 31.3 & 69.7 & & \\
\hline $6(\mathrm{PL}, \mathrm{SE}), \mathrm{DK}, \mathrm{FI}$ & & & & & & no & no \\
\hline Strategy & $0^{*}$ & 8 & 2.4 & $0.6^{*}$ & & & \\
\hline Payoff & 5.5 & 7.1 & 37.3 & 30.2 & 80.1 & & \\
\hline 7 (PL, DK), FI, SE & & & & & & yes & no \\
\hline Strategy & $2.2^{*}$ & $0^{*}$ & 1.6 & 0 & & & \\
\hline Payoff & 7.3 & 1.5 & 28.6 & 32.2 & 69.7 & & \\
\hline $8 \mathrm{PL},(\mathrm{FI}, \mathrm{SE}, \mathrm{DK})$ & & & & & & yes & no \\
\hline Strategy & 2.2 & $0^{*}$ & $0^{*}$ & $0^{*}$ & & & \\
\hline Payoff & 10.2 & 4.4 & 31.9 & 35.4 & 81.9 & & \\
\hline 9 (PL, FI, SE), DK & & & & & & yes & no \\
\hline Strategy & $0^{*}$ & 9.6 & $0^{*}$ & $0^{*}$ & & & \\
\hline Payoff & 9.7 & 9.9 & 39.4 & 37.9 & 96.9 & & \\
\hline 10 (PL, DK, FI), SE & & & & & & yes & no \\
\hline Strategy & $0^{*}$ & $0^{*}$ & $3.4^{*}$ & 2.4 & & & \\
\hline Payoff & 10.7 & 8.9 & 30.5 & 48.3 & 98.4 & & \\
\hline 11 (PL, DK, SE), FI & & & & & & yes & no \\
\hline Strategy & $0^{*}$ & $0^{*}$ & 3.4 & $2.4^{*}$ & & & \\
\hline Payoff & 8.9 & 7.1 & 50.0 & 32.3 & 98.4 & & \\
\hline 12 (PL, DK, FI, SE) & & & & & & yes & yes \\
\hline Strategy & $0^{*}$ & $0^{*}$ & $0^{*}$ & $0^{*}$ & & & \\
\hline Payoff & 15.3 & 15.1 & 55.2 & 53.5 & 139.2 & & \\
\hline
\end{tabular}

Note: Coalition members are shown in parentheses. Payoff of each player and the total payoff are in million euros $(\mathrm{M} €)$. Strategy is the Nash equilibrium fishing effort strategy of each player shown as a ratio to the reported fishing effort in the base year (2010).

* Strategy of the coalition member.

benefits from recreational fisheries. This result highlights the economic relevance of the recreational fisheries for Baltic salmon. Thus, in our model accounting for recreational fisheries not only changes the commercial fisheries' efforts but has also the potential to foster a higher level of international cooperation in the management of the stock.

In our model, the optimal fishing strategies imply significant transfers between coalition members. For instance, under the three stable coalition strictures in scenario 1 (C8, C10, and $\mathrm{C} 11$ ), the harvest of the coalition is undertaken only by the most efficient country. Hence, the payoffs of the remaining members correspond to transfers. Although not common in inter- 
national shared fisheries, transfers, or side payments, have been applied in some IFAs. Miller et al. (2013) refer to the case of the Pacific Salmon Treaty between the USA and Canada. They also point out that the advantages of transfers to foster cooperation in shared fisheries have been discussed at the international policy level (e.g., FAO 2002; Lodge et al. 2007).

\section{IMPLICATIONS FOR SALMON STOCKS}

As shown in the previous section, IFAs on Baltic salmon can take many forms in terms of member countries and harvesting strategies. Hence, the various IFAs have different impacts on the salmon stocks. Figure 2 illustrates the number of juvenile salmon (smolts) under the different scenarios and respective stable coalition structures. Not surprisingly, full cooperation under scenario 2, where the commercial fisheries would not operate, yields the highest number of smolts. The result is subject to the assumption of a constant harvest rate of recreational fisheries. ${ }^{2}$ Moreover, the grand coalition in scenario 2 is the only case in which the management objective, $75 \%$ of the estimated median smolt production capacity, is always met at the end of the simulation period.

According to figure 2, the stable coalition structure with the highest aggregate payoff in scenario 1 (S1/C10) achieves the management objective during the simulation period for all rivers but Simojoki. Another interesting result is that for the majority of rivers, non-cooperation in scenario $2(\mathrm{~S} 2 / \mathrm{C} 1)$ yields a higher number of smolts than the stable partial cooperative agreement with the highest aggregate payoff in scenario 1 (S1/C10). Overall, the main message that emerges from figure 2 is that accounting for the benefits of recreational fisheries is generally positive in terms of stock conservation. In fact, under stable agreements the stock, at the end of the simulation period, is always higher in scenario 2. The same holds true for full non-cooperation (C1), with the exception of the Mörrum River.

\section{DISCUSSION AND CONCLUSION}

This article studies the impact of non-market values on the stability of an international fisheries agreement on Baltic salmon. The results obtained, excluding non-market values, are in line with earlier studies, showing that coalition formation increases incentives for free riding; hence, IFAs are rarely self-enforcing (Pintassilgo 2003; Kulmala et al. 2013). By including non-market values we show that the level of cooperation among harvesting countries increases, and despite the existence of PEs, it is possible to achieve a stable grand coalition. This outcome depends on the overall structure of the fishery and cannot be generalized. What we can conclude from our applied study is that accounting for recreational benefits may affect the level of cooperation in a fishery, possibly due to the increased asymmetry between countries. Following Pintassilgo et al. (2010), it seems plausible to expect that accounting for recreational benefits will increase (decrease) the level of cooperation if it increases (decreases) the asymmetry between the harvesting countries. In our model, accounting for recreational benefits helps not only to achieve the grand coalition but also to ensure that the biological management objective is met. Furthermore, the results show that considering the benefits from recreational fisheries may significantly affect optimal fishing strategies. Taking into account these benefits leads to a decrease in the fishing

\footnotetext{
2. In practice, however, increasing the number of salmon ascending the rivers might attract more anglers. Nonetheless, given their relatively low efficiency compared to operators with commercial gear, the result indicating the largest number of smolts occurring under the grand coalition in scenario 2 should hold.
} 


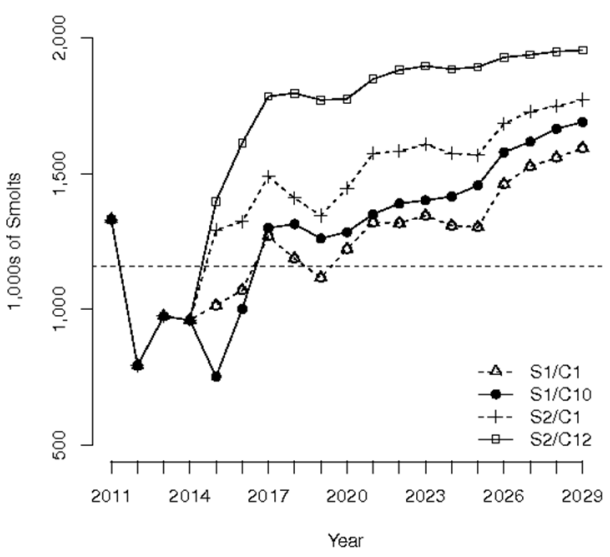

River Kalix

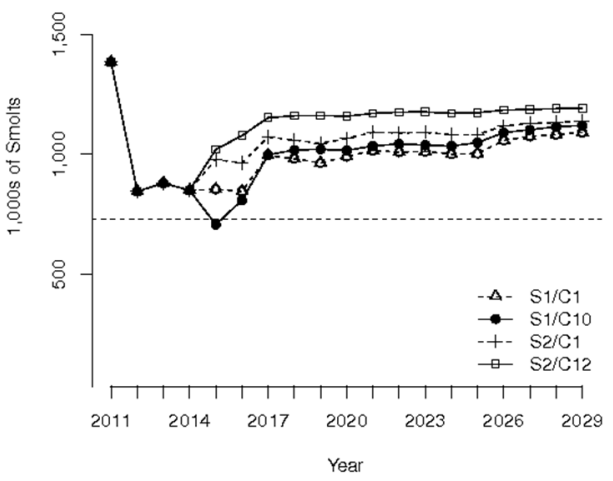

River Ume/Vindel

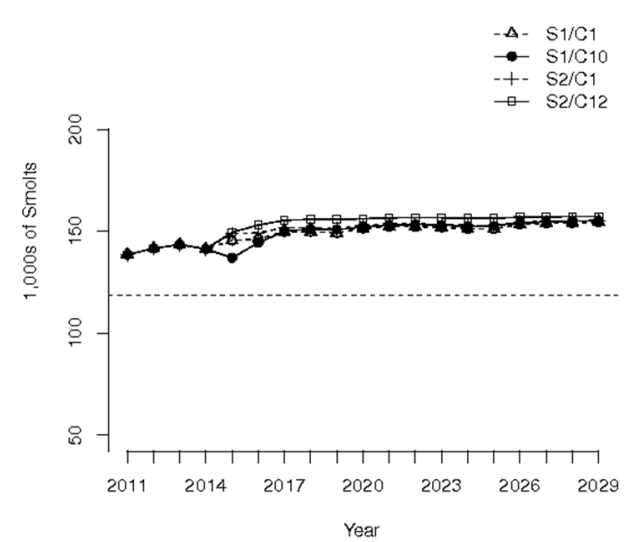

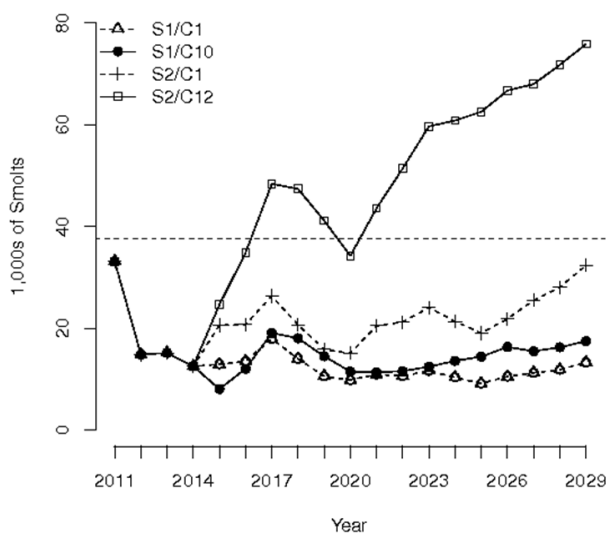

River Byske

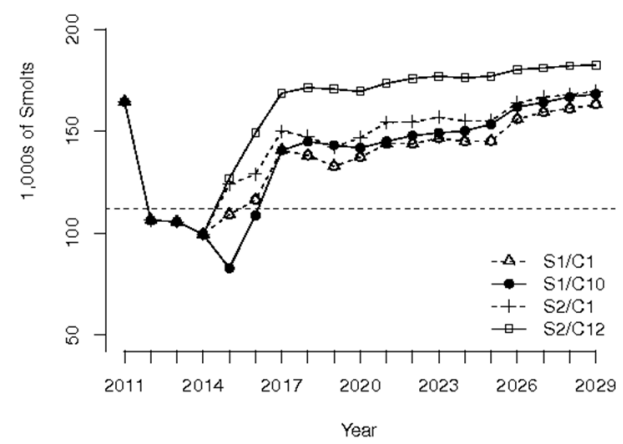

River Mörrum

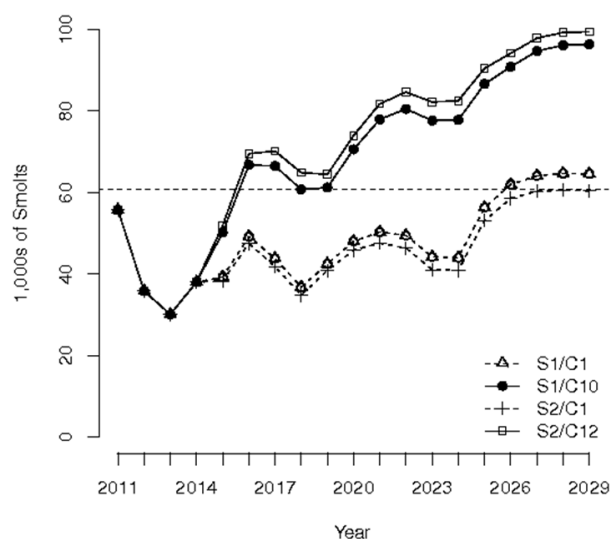

Figure 2. The Number of Smolts for the Two Scenarios (S) with the Respective Non-cooperative Solutions (C1) and the Cooperative Stable Coalition Structures with the Highest Payoffs ( $\mathrm{C} 10$ and $\mathrm{C} 12$ )

Note: The horizontal dotted lines show the management objective: $75 \%$ of the estimated median smolt production capacity (ICES 2012). 
effort of commercial fisheries. This is an expected result, as recreational benefits increase due to the stock level that escapes from commercial fishing. Hence, this result should generally hold for any other salmon fishery.

In the two scenarios considered herein, the IFA game on Baltic salmon exhibits the standard properties of PE and GEC. This means that the more countries that join the agreement, the larger the aggregate payoffs from the fishery and the payoffs for non-members and, consequently, the free-rider incentives. Thus, the 'paradox of cooperation' is observed. In scenario 1, excluding recreational benefits, full cooperation yields around three times the aggregate payoff of non-cooperation, yet it cannot be achieved. However, in scenario 2, which considers recreational benefits, achieving full cooperation is relatively less important in terms of aggregate payoff, but is achieved.

Our case study also show that when recreational benefits are accounted for, countries may find it optimal to give up commercial fisheries in order to increase the benefits from recreational fisheries. This is in line with the findings of Laukkanen (2001); Olaussen (2007); and Kulmala, Laukkanen, and Michielsens (2008), showing the economic benefits of the reallocation of salmon catch. Overall, our results on Baltic salmon highlight the economic relevance of recreational fisheries and its implications in terms of fishing allocation policies and international fisheries management. However, as pointed out by Holzer and McConnell (2014) and Abbott (2015), to derive management recommendations from bioeconomic models it is necessary to consider the institutional setting of the fishery at hand, since modeling results are conditional on the assumptions about institutional arrangements for quota allocations. At present, the TAC regime for Baltic salmon considers commercial fisheries only. Estimating the economically and ecologically sound quota for commercial and recreational fisheries would be a worthy extension of the model. Moreover, considering the effect of angler heterogeneity on the stability of the grand coalition and on size of the commercial and recreational quota might yield empirical findings with policy relevance.

Among the limitations of our model are the assumptions of constant prices and constant costs per unit of effort. These classical assumptions create a polar setting. In scenario 1 , constant costs per unit of effort make it optimal for stable coalitions to concentrate all the fishing effort of the commercial fisheries on the most efficient country. The concentration would occur only partially if increasing marginal costs from fishing were considered. In scenario 2 , the assumption of constant prices makes it optimal for the grand coalition to cease commercial fishing. If downward sloping demand curves for fish were considered, the reduction in effort of the commercial fisheries would not have been so dramatic. Hence, our results regarding the allocation of fishing effort among the different countries and fisheries should be understood as a benchmark.

The management of an internationally shared fish stock, such as Baltic salmon, is highly complex and cannot be fully captured through the game theoretical approach provided herein. The main message that our case study highlights is that accounting for non-market values, such as the benefits from recreational fisheries, may have significant impacts on the formation and stability of IFAs. A natural avenue for further research on this topic is to explore the impacts of recreational benefits on IFAs in a theoretical framework. This could help to understand under which conditions the level of cooperation can increase when recreational benefits are accounted for. Another worthwhile extension would be a game setting where different recreational and commercial fisheries are the players. Alternatively, in each country, the bargaining between the different fisheries over fishing effort could be considered. Moreover, our findings call for more theoret- 
ical work on the functional form of the recreational net benefits and data collection related to the number of recreational anglers and their preferences.

\section{REFERENCES}

Abbott, J. K. 2015. "Fighting Over a Red Herring: The Role of Economics in Recreational-commercial Allocation Disputes." Marine Resource Economics 30(1):1-20.

Ahtiainen, H., J. Artell, M. Czajkowski, B. Hasler, L. Hasselström, A. Huhtala, J. Meyerhoff, J.C. R. Smart, T. Söderqvist, M. H. Alemu, D. Angeli, K. Dahlbo, V. Fleming-Lehtinen, K. Hyytiäinen, A. Karlōševa, Y. Khaleeva, M. Maar, L. Martinsen, T. Nõmmann, K. Pakalniete, I. Oskolokaite, and D. Semeniene. 2014. "Benefits of Meeting Nutrient Reduction Targets for the Baltic Sea - A Contingent Valuation Study in the Nine Coastal States." Journal of Environmental Economics and Policy 3(3):1-28.

Appelblad, H. 2001. "The Spawning Salmon as a Resource by Recreational Use. The case of Wild Baltic Salmon and Conditions for Angling in North Swedish Rivers." Department of Social and Economic Geography, Umeå University, Umeå, Sweden.

Barrett, S. 1994. "Self-enforcing International Environmental Agreements." Oxford Economic Papers 46: $878-94$.

Cantrell, R. N., M. Garcia, P-S. Leung, and D. Ziemann. 2004. "Recreational Anglers' Willingness to Pay for Increased Catch Rates of Pacific Threadfin (Polydactylus sexfilis) in Hawaii." Fisheries Research 68 (1-3):149-58.

Carraro C., and D. Siniscalco. 1993. "Strategies for the International Protection of the Environment." Journal of Public Economics 52(3):309-28.

Carson, R. 2012. Contingent Valuation: A Comprehensive Bibliography and History. Cheltenham, UK: Edward Elgar Publishing.

Chadwick, E. M. P. 1985. "The Influence of Spawning Stock on Production and Yield of Atlantic Salmon, Salmo salar L., in Canadian Rivers." Aquaculture and Fisheries Management 16(1):111-19.

Cook, B. A., and R. L. McGaw. 1996. "Sport and Commercial Fishing Allocations for the Atlantic Salmon Fisheries of the Miramichi River." Canadian Journal of Agricultural Economics 44(2):165-71.

D’Aspremont, C. A. J., J. J. Gabszewicz, and A. Weymark. 1983. "On the Stability of Collusive Price Leadership." The Canadian Journal of Economics 16(1):17-25.

European Commission. 2011. "Proposal for a Regulation of the European Parliament and of the Council. Establishing a Multiannual Plan for the Baltic Salmon Stock and Fisheries Exploiting that Stock." COM (2011)470 Final, Brussels, Belgium.

Eyckmans, J., and M. Finus. 2004. "An Almost Ideal Sharing Scheme for Coalition Games with Externalities.” Working Paper (155.04), Fondazione Eni Enrico Mattei, Milano, Italy.

FAO. 2002. "Report of the Norway-FAO Expert Consultation on the Management of Shared Fish Stocks." Bergen, Norway, 7-10 October, 2002. FAO Fisheries Report 695, FAO, Rome.

Ferrara, I., and P. C. Missios. 1998. "Non-use Values and the Management of Transboundary Renewable Resources." Ecological Economics 25(3):281-89.

Finnish Game and Fisheries Research Institute. 2009. "Data Analysis to Support the Development of a Baltic Sea Salmon Managment Plan." Helsinki.

Gong, M., and G. Heal. 2014. "Why do People Care about Sea Lions? A Fishing Game to Study the Value of Endangered Species." Environmental and Resource Economics 59(4):503-23.

Håkansson, C. 2008. "A New Valuation Question: Analysis of and Insights from Interval Open-ended Data in Contingent Valuation." Environmental and Resource Economics 39(2):175-88.

Hart S., and M. Kurz. 1983. "Endogenous Formation of Coalitions." Econometrica 51(4):1047-64.

Holzer, J., and K. McConnell. 2014. "Harvesting Allocation without Property Rights.” Journal of the Association of Environmental and Resource Economics 1(1/2):209-32. 
Hyytiäinen, K., L. Ahlvik, H. Ahtiainen, J. Artell, A. Huhtala, and K. Dahlbo. 2015. "Policy Goals for Improved Water Quality in the Baltic Sea: When do the Benefits Outweigh the Costs?" Environmental and Resource Economics 61(2):217-41.

ICES. 2012. "Report of the Baltic Salmon and Trout Working Group (WGBAST).” 15-23 March, Uppsala, Sweden.

- 2013. "Report of the Baltic Salmon and Trout Assessment Working Group (WGBAST)." 3-12 April, ICES CM 2013/ACOM:08, Tallinn, Estonia.

- 2014. "Report of the Baltic Salmon and Trout Assessment Working Group (WGBAST)." 26 March-2 April, ICES CM 2014/ACOM:08, Århus, Denmark.

Johnston, R. J., M. H. Ranson, E. Y. Besedin, and E. C. Helm. 2006. "What Determines Willingness to Pay per Fish? A Meta-Analysis of Recreational Fishing Values.” Marine Resource Economics 21(1):1-32.

Karlsson, L., and Ö Karlström. 1994. "The Baltic Salmon (Salmo salar L.): Its History, Present Situation and Future." Dana 10:61-85.

Kragt, M. E. 2013. "Hydro-economic Modelling in an Uncertain World: Integrating Costs and Benefits of Water Quality Management." Water Resources and Economics 4(0):1-21.

Kulmala, S. 2009. "Essays on the Bioeconomics of the Northern Baltic Fisheries." Doctoral dissertation, Department of Economics and Management, University of Helsinki, Helsinki, Finland.

Kulmala, S., M. Laukkanen, and C. G. J. Michielsens. 2008. "Reconciling Economic and Biological Modeling of Migratory Fish Stocks: Optimal Management of the Atlantic Salmon Fishery in the Baltic Sea." Ecological Economics 64(4):716-28.

Kulmala, S., P. Levontin, M. Lindroos, and P. Pintassilgo. 2013. "Atlantic Salmon Fishery in the Baltic Sea-A Case of Trivial Cooperation?" Strategic Behavior and the Environment 3(1-2):121-47.

Laukkanen, M. 2001. "A Bioeconomic Analysis of the Northern Baltic Salmon Fishery: Coexistence versus Exclusion of Competing Sequential Fisheries." Environmental and Resource Economics 18(3):293315.

Lindroos, M., L. Grønbæk Kronbak, and V. Kaitala. 2007. “Coalitions in Fisheries Games.” In Advances in Fisheries Economics: Festschrift in Honour of Professor Gordon R. Munro, ed. T. Bjørndal, D. V. Gordon, R. Arnason, and U. R. Sumaila, 184-95. Oxford: Blackwell.

Lodge, M. W., D. Anderson, T. Lǿbach, G. Munro, K. Sainsbury, and A. Willock. 2007. Recommended Best Practices for Regional Fisheries Management Organizations: Report of an Independent Panel to Develop a Model for Improved Governance by Regional Fisheries Management Organizations. London: Chatham House.

Long, L. K., and O. Flaaten. 2011. "A Stackelberg Analysis of the Potential for Cooperation in Straddling Stock Fisheries.” Marine Resource Economics 26(2):119-39.

Mazzanti, M. 2001. “The Role of Economics in Global Management of Whales: Re-forming or Re-founding IWC?” Ecological Economics 36(2):205-21.

Michielsens, C. G. J., and M. McAllister. 2004. "A Bayesian Hierarchical Analysis of Stock-recruit Data: Quantifying Structural and Parameter Uncertainties." Canadian Journal of Fisheries and Aquatic Sciences 61(6):1032-47.

Michielsens, C. G. J., M. McAllister, S. Kuikka, S. Mäntyniemi, A. Romakkaniemi, T. Pakarinen, L. Karlsson, and L. Uusital. 2008. "Combining Multiple Bayesian Data Analyses in a Sequential Framework for Quantitative Fisheries Stock Assessment.” Canadian Journal of Fisheries and Aquatic Sciences 65(5):962-74.

Michielsens, C. G. J., M. McAllister, S. Kuikka, T. Pakarinen, L. Karlsson, A. Romakkaniemi, I. Pera, and S. Mäntyniemi. 2006. "A Bayesian Statespace Mark-recapture Model to Estimate Exploitation Rates in Mixed-Stock Fisheries." Canadian Journal of Fisheries and Aquatic Sciences 63(14):321-34.

Miller, K. A., G. Munro, U. R. Sumaila, and W. L. Cheung. 2013. "Governing Marine Fisheries in a Changing Climate: A Game-Theoretic Perspective." Canadian Journal of Agricultural Economics 61:309-34. 
Munro, G. 2007. "Internationally Shared Fish Stocks, the High Seas, and Property Rights in Fisheries." Marine Resource Economics 22(4):425-43.

Olaussen, J. O. 2007. "Playing Chicken with Salmon." Marine Resource Economics 22(2):173-93.

Olaussen, J. O., and A. Skonhoft. 2008. "A Bioeconomic Analysis of a Wild Atlantic Salmon (Salmo salar) Recreational Fishery.” Marine Resource Economics 23(3):273-93.

Parkkila, K. 2005. "Estimating the Willingness to Pay for Catch Improvements in the River Simojoki-An Application of Contingent Valuation Method" (abstract in English). Master's thesis, Department of Economics and Management, University of Helsinki.

Pintassilgo, P. 2003. "A Coalition Approach to the Management of High Seas Fisheries in the Presence of Externalities." Natural Resource Modeling 16(2):175-97.

Pintassilgo, P., M. Finus, M. Lindroos, and G. Munro. 2010. "Stability and Success of Regional Fisheries Management Organizations." Environmental and Resource Economics 46(3):377-402.

Pintassilgo, P., L. Grønbæk Kronbak, and M. Lindroos, M. 2015. "International Fisheries Agreements: A Game Theoretical Approach.” Environmental and Resource Economics 62(4):689-709.

Pintassilgo, P., and M. Lindroos. 2008. "Coalition Formation in Straddling Stock Fisheries: A Partition Function Approach.” International Game Theory Review 10(3):303-17.

Romakkaniemi, A., I. Pera, L. Karlsson, E. Jutila, U. Carlsson, and T. Pakarinen. 2003. "Development of Wild Atlantic Salmon Stocks in the Rivers of the Northern Baltic Sea in Response to Management Measures." ICES Journal of Marine Science: Journal du Conseil 60(2):329-42.

Thrall, R., and W. Lucas. 1963. "N-person Games in Partition Function Form." Naval Research Logistics Quarterly 10:281-98.

United Nations. 1982. "United Nations Convention on the Law of the Sea." UN Doc. A/Conf. 62/122, Monetgo Bay, Jamaica.

_ 1995. "United Nations Conference on Straddling Fish Stocks and Highly Migratory Fish Stocks. Agreement for the Implementation of the Provisions of the United Nations Convention on the Law of the Sea of 10 December 1982 Relating to the Conservation and Management of Straddling Fish Stocks and Highly Migratory Fish Stocks." UN Doc. A/Conf./164/37, New York, NY.

Von Neumann, J., and O. Morgenster. 1944. Theory of Games and Economic Behavior. Princeton, NJ: Princeton University Press.

Yi, S. S. 1997. "Stable Coalition Structures with Externalities." Games and Economic Behavior 20(2):201-37. 
Copyright of Marine Resource Economics is the property of University of Chicago Press and its content may not be copied or emailed to multiple sites or posted to a listserv without the copyright holder's express written permission. However, users may print, download, or email articles for individual use. 